\title{
Cellular Plasticity for Group I mGluR-Mediated Epileptogenesis
}

\author{
Riccardo Bianchi, Shih-Chieh Chuang, Wangfa Zhao, Steven R. Young, and Robert K. S. Wong \\ The Robert F. Furchgott Center for Neural and Behavioral Science and Department of Physiology and Pharmacology, State University of New York \\ Downstate Medical Center, Brooklyn, New York 11203
}

\begin{abstract}
Stimulation of group I metabotropic glutamate receptors (mGluRs) by the agonist $(S)$-dihydroxyphenylglycine in the hippocampus transforms normal neuronal activity into prolonged epileptiform discharges. The conversion is long lasting in that epileptiform discharges persist after washout of the inducing agonist and serves as a model of epileptogenesis. The group I mGluR model of epileptogenesis took on special significance because epilepsy associated with fragile X syndrome (FXS) may be caused by excessive group I mGluR signaling. At present, the plasticity mechanism underlying the group I mGluR-mediated epileptogenesis is unknown. $I_{\mathrm{mGluR}(\mathrm{V})}$, a voltagegated cationic current activated by group I mGluR agonists in CA3 pyramidal cells in the hippocampus, is a possible candidate. $I_{\mathrm{mGluR}(\mathrm{V})}$ activation is associated with group I mGluR agonist-elicited epileptiform discharges. For $I_{\mathrm{mGluR}(\mathrm{V})}$ to play a role in epileptogenesis, long-term activation of the current must occur after group I mGluR agonist exposure or synaptic stimulation. We observed that $I_{\mathrm{mGluR}(\mathrm{V})}$, once induced by group I mGluR agonist stimulation in CA3 pyramidal cells, remained undiminished for hours after agonist washout. In slices prepared from FXS model mice, repeated stimulation of recurrent CA3 pyramidal cell synapses, effective in eliciting mGluRmediated epileptiform discharges, also induced long-lasting $I_{\mathrm{mGluR}(\mathrm{V})}$ in CA3 pyramidal cells. Similar to group I mGluR-mediated prolonged epileptiform discharges, persistent $I_{\mathrm{mGluR}(\mathrm{V})}$ was no longer observed in preparations pretreated with inhibitors of tyrosine kinase, of extracellular signal-regulated kinase $1 / 2$, or of mRNA protein synthesis. The results indicate that $I_{\mathrm{mGluR}(\mathrm{V})}$ is an intrinsic plasticity mechanism associated with group I mGluR-mediated epileptogenesis.
\end{abstract}

\section{Introduction}

Considerable information on group I metabotropic glutamate receptor (mGluR)-mediated epileptogenesis has been derived from experiments using the group I mGluR agonist $(S)$ dihydroxyphenylglycine (DHPG) to stimulate hippocampal slices (Merlin and Wong, 1997; Merlin et al., 1998; Chuang et al., 2001; McNamara et al., 2006). In response to group I mGluR agonist stimulation, rhythmic synchronized discharges of prolonged durations (up to $10 \mathrm{~s}$ ) appeared in the CA3 neuronal population. Each episode of prolonged synchronized discharge consists of fast membrane oscillations of $12-24 \mathrm{~Hz}$ with overriding action potential discharges. Blockade of GABA-mediated inhibition is not required for the occurrence of these discharges (Taylor et al., 1995; Zhao et al., 2004). The features of these prolonged synchronized discharges can be compared with ictal discharges recorded during seizures (Lieb et al., 1981). Two notable properties of the group I mGluR-mediated prolonged discharges elicited in hippocampal slices are as follows: (1) prolonged discharges, once induced, persist even when the inducing agonist is washed out (Merlin and Wong, 1997); and (2) induction of the prolonged discharges is dependent on group I mGluR-activated

Received Nov. 11, 2008; revised Feb. 10, 2009; accepted Feb. 15, 2009.

This work was supported by the Fragile X Research Foundation and National Institutes of Health Grant NS35481. Correspondence should be addressed to Riccardo Bianchi, Department of Physiology and Pharmacology, Box 29, State University of New York Downstate Medical Center, 450 Clarkson Avenue, Brooklyn, NY 11203. E-mail: rbianchi@downstate.edu.

DOI:10.1523/JNEUROSCI.5447-08.2009

Copyright $\odot 2009$ Society for Neuroscience $\quad$ 0270-6474/09/293497-11\$15.00/0
mRNA translation that is mediated via a tyrosine kinaseextracellular signal-regulated kinase (ERK) 1/2 signaling cascade (Zhao et al., 2004).

In addition to agonist stimulation, synaptically released glutamate also activates group I mGluRs in the hippocampal CA3 population (Bianchi and Wong, 1995; Lee et al., 2002). However, synaptic stimulation is ineffective at eliciting the mGluRdependent prolonged synchronized discharges (Lee et al., 2002). This is attributable to the negative regulation of group I mGluRactivated mRNA translation by the fragile $\mathrm{X}$ mental retardation protein (FMRP) (Weiler et al., 1997; Huber et al., 2002; Aschrafi et al., 2005; Chuang et al., 2005; Hou et al., 2006). FMRP is absent in fragile X syndrome (FXS) because of a trinucleotide (CGG) repeat expansion of the promoter of the Fmrl gene (Penagarikano et al., 2007). Under this condition, group I mGluRdependent protein synthesis is enhanced, enabling the synaptic induction of group I mGluR-mediated prolonged discharges (Chuang et al., 2005). In vivo studies show that FXS model mice have heightened susceptibility to audiogenic seizures mediated by group I mGluR activation, as these seizures are suppressed by group I mGluR antagonist (Yan et al., 2005).

Recordings in the wild-type CA3 pyramidal cells show that a voltage-dependent cationic current, $I_{\mathrm{mGluR}(\mathrm{V})}$, was activated accompanying group I mGluR-dependent prolonged discharges (Chuang et al., 2001). $I_{\text {mGluR(V) }}$ has an activation threshold ( -65 $\mathrm{mV}$ ) close to the resting potential, a reversal potential of approximately $-10 \mathrm{mV}$, and shows no inactivation (Chuang et al., 2000, 2001). $I_{\mathrm{mGluR}(\mathrm{V})}$ alters the properties of CA3 pyramidal cells by 
inducing bistable resting potentials and by eliciting rhythmic, prolonged trains of action potentials (up to $12 \mathrm{~s}$ ). Rhythmic prolonged firing in individual CA3 pyramidal cells provides the basic activity pattern which, when synchronized via the recurrent synapses, sustains the prolonged epileptiform discharges in the CA3 population (Wong et al., 2004). In this study, we found that agonist-induced $I_{\mathrm{mGluR}(\mathrm{V})}$ is long lasting and that $I_{\mathrm{mGluR}(\mathrm{V})}$ can be induced synaptically in association with the group I mGluRmediated prolonged epileptiform discharges.

\section{Materials and Methods}

Slice preparation. Fmr1-/- mice and littermates were obtained from The Jackson Laboratory. Transverse hippocampal slices (300-400 $\mu \mathrm{m}$ thick) were prepared from 2- to 7-week-old mice or 2- to 4-week-old guinea pigs as described previously (Chuang et al., 2005; Bianchi et al., 2006), according to procedures approved by the Institutional Animal Care and Use Committee of the State University of New York Downstate Medical Center, Brooklyn, NY. Hippocampi were dissected out in icecold solution (containing, in mM: $124 \mathrm{NaCl}, 26 \mathrm{NaHCO}_{3}, 2.5 \mathrm{KCl}, 8$ $\mathrm{MgCl}_{2}, 0.5 \mathrm{CaCl}_{2}$, and $10 \mathrm{D}$-glucose), glued to the stage of a Lancer Vibratome 1000 (The Vibratome Company), and sliced. For patchclamp recordings, single slices were submerged in a coverslip-bottomed recording chamber (Luigs \& Neumann) and superfused with artificial CSF (aCSF) containing (in $\mathrm{mm}$ ) $124 \mathrm{NaCl}, 26 \mathrm{NaHCO}_{3}, 5 \mathrm{KCl}, 1.6$ $\mathrm{MgCl}_{2}, 2 \mathrm{CaCl}_{2}$, and D-10 glucose, gassed with a $95 \% \mathrm{O}_{2}-5 \% \mathrm{CO}_{2}(\mathrm{pH}$ $\left.7.4 ; 31-32^{\circ} \mathrm{C}\right)$. The $\mathrm{Mn}^{2+}$ /low $\mathrm{Ca}^{2+}$-containing solution $\left(\mathrm{Mn}^{2+}\right.$ solution) had the same composition as the aCSF except for $0.2 \mathrm{mM} \mathrm{CaCl}_{2}$ and added $1 \mathrm{~mm} \mathrm{MnCl}_{2}$. The chamber was on a remotely controlled stationary stage with mounted micromanipulators (Luigs \& Neumann) under an upright microscope equipped with water-immersion objectives and infrared differential interference contrast microscopy (BX50WI; Olympus). Neurons in the slice were visualized through a solid-state camera (Cohu) connected to a video monitor. For intracellular recordings, slices were placed in an interface recording chamber (Fine Science Tools) and perfused with aCSF $\left(34-36^{\circ} \mathrm{C}\right)$.

Electrophysiology. Data shown in Figures 2-6 and supplemental Figures S1 and S2, $A$ and $B$ (available at www.jneurosci.org as supplemental material), are from visually identified CA3 pyramidal cells recorded in whole-cell voltage-clamp using glass pipettes (3-6 M $\Omega$; World Precision Instruments) and a patch-clamp amplifier (EPC-7; HEKA Instruments). Recording pipettes were filled with solution containing the following (in $\mathrm{mm}$ ): $119 \mathrm{~K}^{+}$gluconate, $13 \mathrm{KCl}, 10$ HEPES, $5 \mathrm{NaCl}, 2 \mathrm{CsCl}, 2 \mathrm{Mg}$-ATP, 2 EGTA, and $\mathrm{pH}$ was adjusted to 7.3 with $\mathrm{KOH}$. For intracellular application of $\mathrm{Cs}^{+}$, the pipette solution contained (in $\mathrm{mM}$ ) the following: 119 $\mathrm{CsCH}_{3} \mathrm{SO}_{3}, 10$ HEPES, $5 \mathrm{NaCl}, 15 \mathrm{CsCl}, 2 \mathrm{Mg}$-ATP, 2 EGTA (pH 7.3). Signals were sampled at $3 \mathrm{kHz}$, digitized at $0.1-1 \mathrm{kHz}$ on an Intel-based computer running pCLAMP software (Molecular Devices), and simultaneously displayed on an oscilloscope (DSO 400; Gould Instruments) and on a chart recorder (TA240; Gould Instruments). Intracellular recordings shown in Figures 1 and 7 and supplemental Figure S2, $C$ and $D$ (available at www.jneurosci.org as supplemental material), were obtained from slices placed in the interface chamber via an Axoclamp 2A amplifier (Molecular Devices). Membrane currents were recorded in single-electrode discontinuous voltage-clamp mode. Thin-walled glass electrodes were filled with potassium acetate $(2 \mathrm{M} ; 30-50 \mathrm{M} \Omega$ ).

Data analysis. The amplitude of $I_{\mathrm{mGluR}(\mathrm{V})}$ was obtained from the term " $a$ " in the equation $y=y_{0}+a e^{-\mathrm{bx}}$ of the best fitting function $(R>0.9)$. Fits and plots were obtained using Sigma Plot 8 (Systat Software). Average data were expressed as mean \pm SEM. Student's $t$ test and ANOVA with post hoc Newman-Keuls test were used for statistical comparisons with significance set at $p=0.05$ (GB STAT; Dynamic Microsystems)

Pharmacological agents. Agents were stored in stock solutions at $-80^{\circ} \mathrm{C}$ for no more than 1-2 weeks and diluted into the perfusing solution at the indicated final concentrations at the time of the experiments. DHPG, 6-cyano7-nitroquinoxaline-2,3-dione (CNQX), (RS)-3-(2-carboxypiperazin-4yl)propyl-1-phosphonic acid (CPP), ( $S$ )- $\alpha$-methyl-4-carboxyphenylglycine (MCPG), 2-methyl-6-(phenylethynyl)pyridine hydrochloride (MPEP), (S)-(+)- $\alpha$-amino-4-carboxy-2-methylbenzeneacetic acid (LY367385), and cycloheximide were purchased from Tocris Bioscience. Genistein, 1,4diamino-2,3-dicyano-1,4-bis(2-aminophenylthio)butadiene (U0126), and 2-amino-3-methoxyflavone (PD98059) were obtained from Calbiochem. All the other chemicals were from Sigma-Aldrich. We note that CNQX can have excitatory actions on a subset of interneurons (although not on excitatory neurons) (McBain et al., 1992; Brickley et al., 2001; Maccaferri and Dingledine, 2002; Hashimoto et al., 2004; see also Menuz et al., 2007). To evaluate possible actions of CNQX on our recorded cells, we measured, in current clamp, membrane potential $\left(V_{\mathrm{m}}\right)$ and input resistance $\left(R_{\mathrm{in}}\right)$ of five CA3 pyramidal cells before $\left(V_{\mathrm{m}}-65.7 \pm 1.0 \mathrm{mV} ; R_{\mathrm{in}} 48.4 \pm 8.0 \mathrm{M} \Omega\right)$ and $\operatorname{after}\left(V_{\mathrm{m}}-65.8 \pm 0.9 \mathrm{mV} ; R_{\mathrm{in}} 46.3 \pm 6.9 \mathrm{M} \Omega\right) \mathrm{CNQX}$ and CPP application. The results show that these membrane parameters were not significantly affected by $\operatorname{CNQX}\left(V_{\mathrm{m}}, p=0.49 ; R_{\mathrm{in}}, p=0.60\right)$.

\section{Results}

\section{Cellular responses of CA3 pyramidal cells to DHPG}

All data were obtained from intracellular recordings of CA3 pyramidal cells in hippocampal slices isolated from guinea pigs (Figs. 1-6; supplemental Fig. S1, available at www.jneurosci.org as supplemental material) and from wild-type and knock-out mice (Fig. 7; supplemental Fig. S2, available at www.jneurosci.org as supplemental material). Data obtained from mouse preparations are indicated in the figure legends.

Figure 1 shows the effects of the group I mGluR agonist DHPG $(50 \mu \mathrm{M})$ on CA3 pyramidal cells. To characterize the effect of DHPG on single CA3 pyramidal cells, independent of recurrent synaptic activity, ionotropic glutamate receptor (iGluR) antagonists (CNQX plus CPP; $20 \mu \mathrm{M}$ each) were added to the perfusing solution to suppress excitatory synaptic transmission and to block synchronized discharges. Intracellular recordings show that DHPG application elicited prolonged rhythmic depolarizations (5-20 s) with overriding action potentials (prolonged bursts) in single CA3 neurons (Fig. $1 A b, B a$ ). Prolonged bursts occurred at regular intervals of 15-50 s. During the interval, gradual depolarizations (pacemaker potentials) were recorded that reached threshold and elicited another phase of prolonged bursting. Membrane hyperpolarization applied through intracellular current injection during the pacemaker potential reset the membrane potential to a hyperpolarized level (Fig. $1 \mathrm{Bb}$ ). In addition, hyperpolarization applied during the prolonged burst could arrest the burst and terminate the underlying depolarization (Fig. $1 B$ ).

At more depolarized membrane potentials $(>-55 \mathrm{mV})$, DHPG exposure elicited tonic depolarization of CA3 pyramidal cells (Fig. $1 C b$ ). Hyperpolarizing responses elicited by current injection at these membrane potentials (more depolarized than $-55 \mathrm{mV}$ ) followed a significantly slower time course than that observed in control condition, before the addition of DHPG (compare Fig. $1 \mathrm{Ca}$ with $1 \mathrm{Cb}$ ). The voltage response was slow, presumably because the hyperpolarizing pulse now turned off an inward current, $I_{\mathrm{mGluR(V)}}$, that was elicited by DHPG and active at membrane potentials more depolarized than $-55 \mathrm{mV}\left(I_{\mathrm{mGluR}(\mathrm{V})}\right.$ threshold, approximately $-55 \mathrm{mV}$ ) (see Fig. $4 A c$ ). The gradual turn-off of the current, attributable to the slow deactivation time constant of $I_{\operatorname{mGluR}(\mathrm{V})}(\sim 0.54 \mathrm{~s}$ at $-45 \mathrm{mV})$ (Chuang et al., 2000), contributed to the slower hyperpolarizing response elicited by the current pulse. After release of the injected hyperpolarizing current, a fast repolarization of the membrane potential was followed by a secondary, more gradual depolarization (the start of which is indicated by a filled arrow in Fig. $1 \mathrm{Cb}$ ) to the prehyperpolarizing pulse level. The slow depolarization can be compared with the pacemaker potential shown in Figure $1 B$.

DHPG responses elicited in CA3 pyramidal cells were examined under voltage clamp. The time course of the current response was examined after hyperpolarizing pulses $(-100 \mathrm{mV}$; 
A
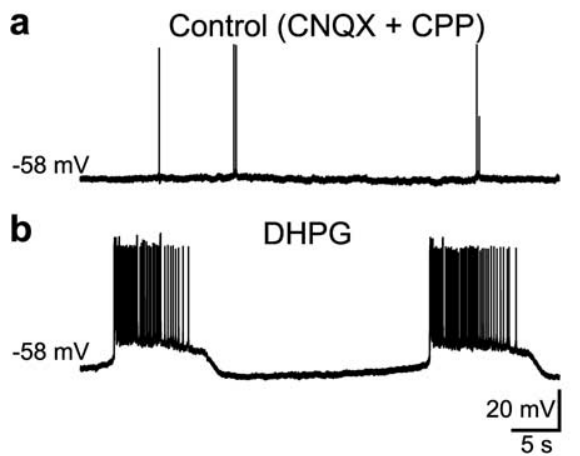

B
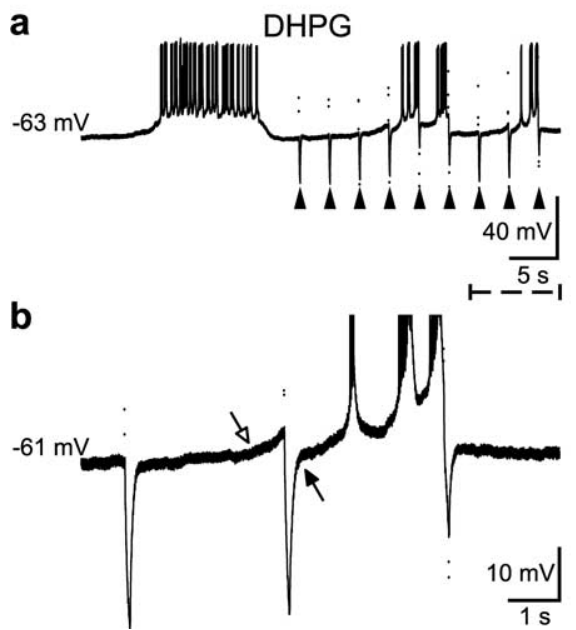

C

a

$-51 \mathrm{mV}$

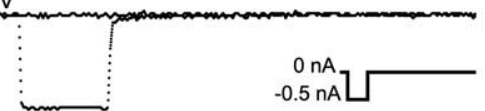

b

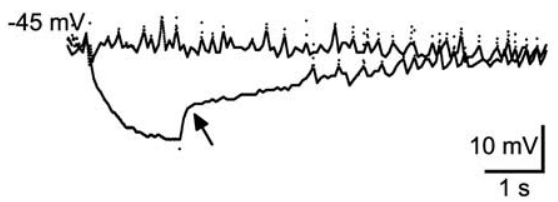

D

a

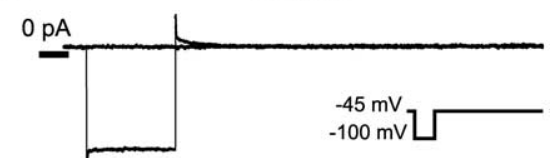

Voltage-clamp

Control

b

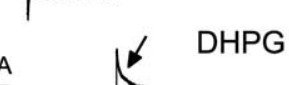

opA

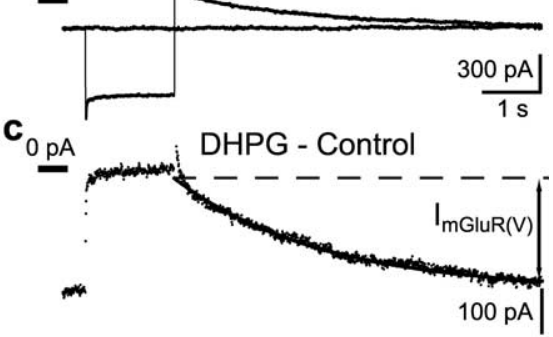

Figure 1. DHPG induces rhythmic prolonged intrinsic bursts in CA3 pyramidal cells. $A$, Intracellular records from synaptically isolated CA3 neurons in CNQX and CPP (20 $\mu \mathrm{m}$ each) before (a) and during DHPG $(50 \mu \mathrm{m} ; \boldsymbol{b})$. Membrane potential values are indicated at the beginning of each current-clamp record. $B$, Application of hyperpolarizing square-wave pulses $(-0.6 \mathrm{nA} ; 100 \mathrm{~ms}$; $0.33 \mathrm{~Hz}$; arrowheads) to the same cell. A segment of the record in $\boldsymbol{a}$ (dashed line) is expanded in $\boldsymbol{b}$. The spontaneous depolarization preceding the burst (pacemaker potential, hollow arrow) is suppressed by the pulse (filled arrow). Plateau depolarization during spontaneous bursting is maintained by $I_{\text {mGluR(V) }}$. During action potential firing, intracellular $\mathrm{Ca}^{2+}$ accumulates (Bianchi et al., 1999), leading to $\mathrm{K}^{+}$current activation (Bianchi et al., 1999). When cumulative $\mathrm{K}^{+}$current activation during the burst exceeds the amplitude of $I_{\text {mGluR(V), }}$, net membrane current becomes outward, causing hyperpolarization, deactivation of $I_{\text {mGluR(V), }}$ and burst termination. C, Voltage responses to a hyperpolarizing pulse (inset) recorded in CNQX and CPP (a) and after addition of DHPG (b). Note that DHPG induced depolarization of the membrane potential above threshold for action potential firing. Action potentials are clipped by digitization. Sustained activation of $I_{\mathrm{mGluR}(\mathrm{V})}$ maintained the resting membrane potential at $-45 \mathrm{mV} . I_{\mathrm{mGluR}(\mathrm{V})}$ was turned off by hyperpolarization and was activated after release of the hyperpolarization (arrow). Thus, non-inactivating $I_{\text {mGluR(V) }}$ contributes to the DHPG-induced depolarization of the resting membrane potential. In $\boldsymbol{C}$ and $\boldsymbol{D}$, responses to pulses are superimposed to baseline records. $\boldsymbol{D}$, Voltage-clamp records obtained in the same conditions as in $\boldsymbol{C}$. The net inward current elicited by DHPG after the pulse $\left(\boldsymbol{D} \boldsymbol{c} ; I_{\mathrm{mGluR}(\mathrm{V})}\right)$ was obtained by subtracting the record in $\boldsymbol{D a}$ from that in $\boldsymbol{D} \boldsymbol{b}$ and was fitted with a single exponential (solid line). The dashed line is the current level extrapolated from the fit at the end of the pulse. Zero current level is indicated for each voltage-clamp record.

$1.5 \mathrm{~s}$ ) applied at a holding potential of $-45 \mathrm{mV}$. Termination of the hyperpolarizing pulse was followed by a slowly developing inward current (Fig. $1 D b$, arrow). The inward current brought the holding current back to the level preceding the hyperpolarizing pulse. The data are consistent with the finding that DHPG activates an inward current $\left(I_{\mathrm{mGluR}(\mathrm{V})}\right)$ in CA3 pyramidal cells. The current is voltage-sensitive in that its amplitude increases with membrane depolarization (Chuang et al., 2000, 2001). In Figure $1 D b, I_{\mathrm{mGluR}(\mathrm{V})}$ was tonically activated at the holding potential of $-45 \mathrm{mV}$. The hyperpolarizing pulse deactivated $I_{\text {mGluR(V) }}$. Immediately after the hyperpolarization pulse, when the membrane potential jumped from -100 to $-45 \mathrm{mV}$, the instantaneous $I_{\mathrm{mGluR}(\mathrm{V})}$ conductance remained at the $-100 \mathrm{mV}$ level. With time, $I_{\mathrm{mGluR}(\mathrm{V})}$ developed, after its activation time constant, to the level appropriate for -45 $\mathrm{mV}$. The gradual activation of $I_{\mathrm{mGluR}(\mathrm{V})}$ caused the gradual depolarization indicated by the arrow in the current-clamp recording in Figure $1 C b$. In subsequent experiments, the time course of $I_{\mathrm{mGluR}(\mathrm{V})}$ activation from hyperpolarized levels to $-45 \mathrm{mV}$ (posthyperpolarization current response) was used to indicate the amplitude of $I_{\mathrm{mGluR}(\mathrm{V})}$ activated in recorded cells (Fig. $1 D c$ ).

The role of group I mGluR subtypes, mGluR1 and mGluR5, in $I_{\text {mGluR(V) }}$ activation, was examined using the specific blockers LY367385 and MPEP, respectively. Blockers were added 10 min before DHPG application. Amplitude of $I_{\mathrm{mGluR}(\mathrm{V})}$ elicited by DHPG was $-116 \pm 16 \mathrm{pA}$ in $15 \mathrm{CA} 3$ pyramidal cells. In slices pretreated with LY367385 $(100 \mu \mathrm{M})$ or MPEP $(50 \mu \mathrm{M})$, $I_{\text {mGluR(V) }}$ amplitude elicited by DHPG was significantly reduced. $I_{\mathrm{mGluR}(\mathrm{V})}$ amplitude elicited in the presence of the mGluR1 antagonist was $24 \%$ of control value $(-28 \pm 8 \mathrm{pA}$; $n=5 ; p<0.01)$. In the presence of the mGluR5 antagonist, $I_{\mathrm{mGluR}(\mathrm{V})}$ amplitude was $33 \%$ of the control value $(-38 \pm 11 \mathrm{pA}$; $n=5 ; p<0.05)$. When both antagonists were applied, $I_{\mathrm{mGluR}(\mathrm{V})}$ amplitude was $-5 \pm$ $4 \mathrm{pA}(n=5)$, not significantly different than that measured in control (i.e., without DHPG, $-6 \pm 3 \mathrm{pA} ; n=15 ; p=0.97)$. The data suggest that DHPG elicited $I_{\mathrm{mGluR}(\mathrm{V})}$ via activation of both mGluR1 and mGluR5. These results are consistent with a previous report demonstrating that $I_{\mathrm{mGluR}(\mathrm{V})}$ elicited by DHPG was significantly attenuated in CA3 neurons from mGluR1 knock-out mice (Chuang et al., 2002). Synergistic action of mGluR1 and mGluR5 on the activation of a DHPG-elicited inward current in CA1 pyramidal cells has also been reported (Rae and Irving, 2004).

\section{Persistent activation of $I_{\mathrm{mGluR}(\mathrm{V})}$}

To isolate $I_{\mathrm{mGluR}(\mathrm{V})}$ from voltage-gated intrinsic $\mathrm{Na}^{+}$and $\mathrm{K}^{+}$currents, slices were perfused in tetrodotoxin (TTX; $1 \mu \mathrm{M}$ ) and $\mathrm{Cs}^{+}(5 \mathrm{~mm})$. In addition, voltage-clamp recordings were performed using $\mathrm{Cs}^{+}$filled (134 mM) pipettes. After the onset of a whole-cell patch recording using $\mathrm{Cs}^{+}$-containing pipettes, an inward current developed with a time constant in the range of $1.7-3.7 \mathrm{~min}(n=8)$ (Fig. 2E). Holding currents became stable after $\sim 10 \mathrm{~min}$. DHPG was routinely applied $30 \mathrm{~min}$ after the onset of whole-cell recording mode, a time span during which baseline holding current was stable.

Cells were held at $-45 \mathrm{mV}$. DHPG (50 $\mu \mathrm{M} ; 20 \mathrm{~min})$ elicited an inward current in CA3 pyramidal cells (Fig. 2A). Periodic hyperpolarizing pulses $(-75 \mathrm{mV})$ were applied during DHPG application. The posthyperpolarization current response was monitored before (control) and during DHPG application. $I_{\mathrm{mGluR}(\mathrm{V})}$ amplitude was obtained by subtracting the control posthyperpolarization current response (Fig. $2 A$, asterisk) from those obtained in the presence of DHPG (Fig. $2 B b, c)$. 
The amplitudes of the holding current and of peak $I_{\mathrm{mGluR}(\mathrm{V})}$ were not altered by DHPG washout (compare Fig. $2 B c$ and $B d)$. Figure $2 D$ shows the average peak $I_{\mathrm{mGluR}(\mathrm{V})}$ amplitude recorded in seven cells during DHPG application and followed for $1 \mathrm{~h}$ after washout. The data indicate that $I_{\mathrm{mGluR}(\mathrm{V})}$ amplitude remained stable throughout the washout period.

\section{Properties of persistent $I_{\mathrm{mGluR}(\mathrm{V})}$}

The properties of $I_{\mathrm{mGluR}(\mathrm{V})}$ elicited during DHPG exposure and after DHPG washout were examined using step depolarization and ramp depolarization command voltages.

Depolarizing steps from -90 to -35 $\mathrm{mV}$ were applied in $15 \mathrm{mV}$ increments (Fig. 3). The perfusing solution contained TTX and $\mathrm{Cs}^{+}$, and $\mathrm{Cs}^{+}$-filled pipettes were used for whole-cell patch recordings. $I_{\mathrm{mGluR}(\mathrm{V})}$ was activated by the depolarizing pulses. The time course of the current during the depolarization (Fig. $3 A$ ) was obtained by subtracting the current responses recorded before DHPG (control) from those recorded during (Fig. 3Aa) or after (Fig. $3 A b$ ) DHPG exposure. $I_{\text {mGluR(V) }}$ was not activated at voltages more hyperpolarized than $-65 \mathrm{mV}$. At $-50 \mathrm{mV}$ and above, the current increased in amplitude with increased depolarization. The amplitudes of $I_{\text {mGluR(V) }}$ activated by DHPG at different levels of depolarization were not altered by DHPG washout (Fig. $3 A, B$ ).

To explore $I_{\mathrm{mGluR}(\mathrm{V})}$ properties over a more extended membrane potential range, a ramp voltage command from -70 to $-5 \mathrm{mV}$ was applied (Fig. 4). As before, intrinsic $\mathrm{Na}^{+}$current was suppressed by TTX and $\mathrm{K}^{+}$current by $\mathrm{Cs}^{+}$in the extracellular and intracellular solutions. In addition, voltage-dependent $\mathrm{Ca}^{+}$currents were suppressed using a $\mathrm{Mn}^{2+}(1 \mathrm{~mm}) /$ low $\mathrm{Ca}^{2+}(0.2 \mathrm{~mm})$ solution $\left(\mathrm{Mn}^{2+}\right.$ solution). Figure $4 \mathrm{Aa}$ shows the initial activation of the $\mathrm{Ca}^{2+}$ current by the ramp command and the subsequent gradual suppression of the $\mathrm{Ca}^{2+}$ current during the wash-in of the $\mathrm{Mn}^{2+}$ solution. The $\mathrm{Ca}^{2+}$ current, with peak activation around $-10 \mathrm{mV}$ (Fig. $4 \mathrm{Ac}$ ), was completely suppressed after $23 \mathrm{~min}$ of perfusion with the $\mathrm{Mn}^{2+}$ solution. After the $\mathrm{Ca}^{2+}$ current suppression, responses to the ramp depolarization became linear over the voltage range tested (Fig. $4 A a, b$, Control). DHPG elicited nonlinear responses with the activation of a U-shaped current profile at depolarized voltages (Fig. $4 A b$, DHPG). Subtraction of the control current responses from those elicited in DHPG provided the current-voltage $(I-V)$ relationship and amplitude of the DHPG-activated current $\left(I_{\mathrm{mGluR}(\mathrm{V})}\right)$ (Fig. 4Ac). Maximum $I_{\mathrm{mGluR}(\mathrm{V})}$ amplitude, its activation threshold, its reversal potential, and peak activation voltage were measured from the $I-V$ curve, and these parameters were all distinct from those recorded for the $\mathrm{Ca}^{2+}$ current. Figure $4, B$ and $C$, $\left(R^{2}>0.91\right)$.
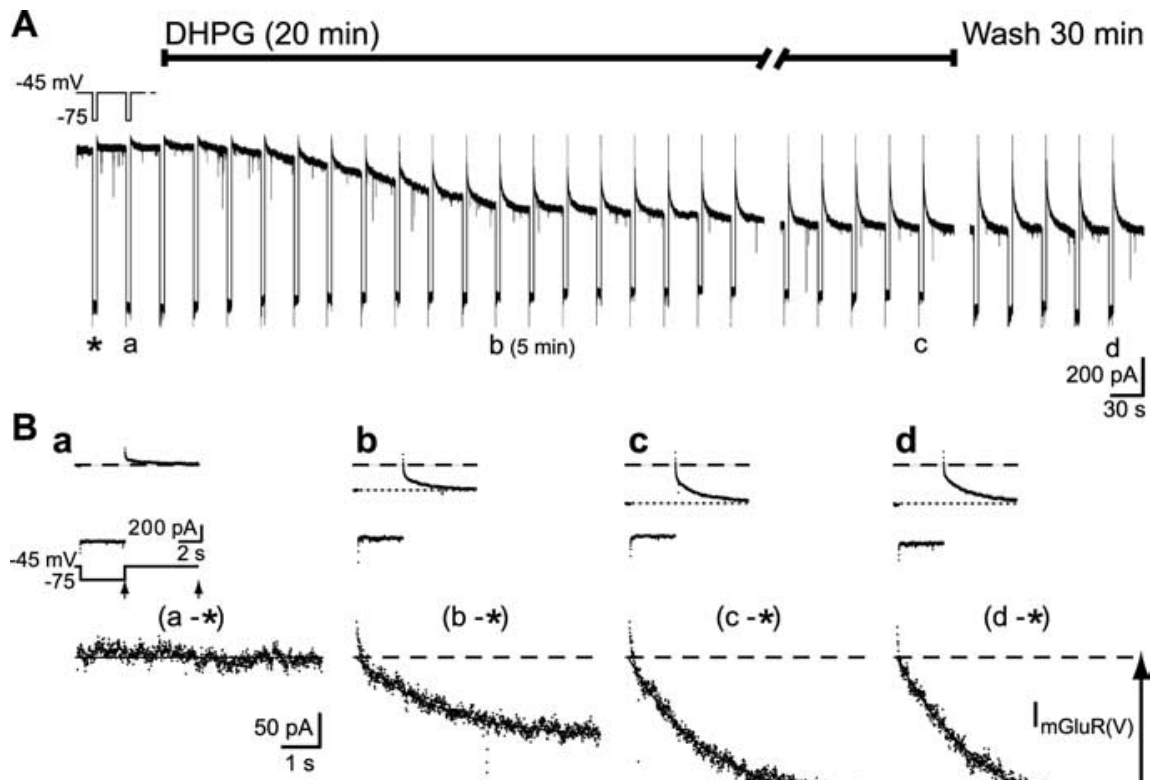

$30 \mathrm{~s}$
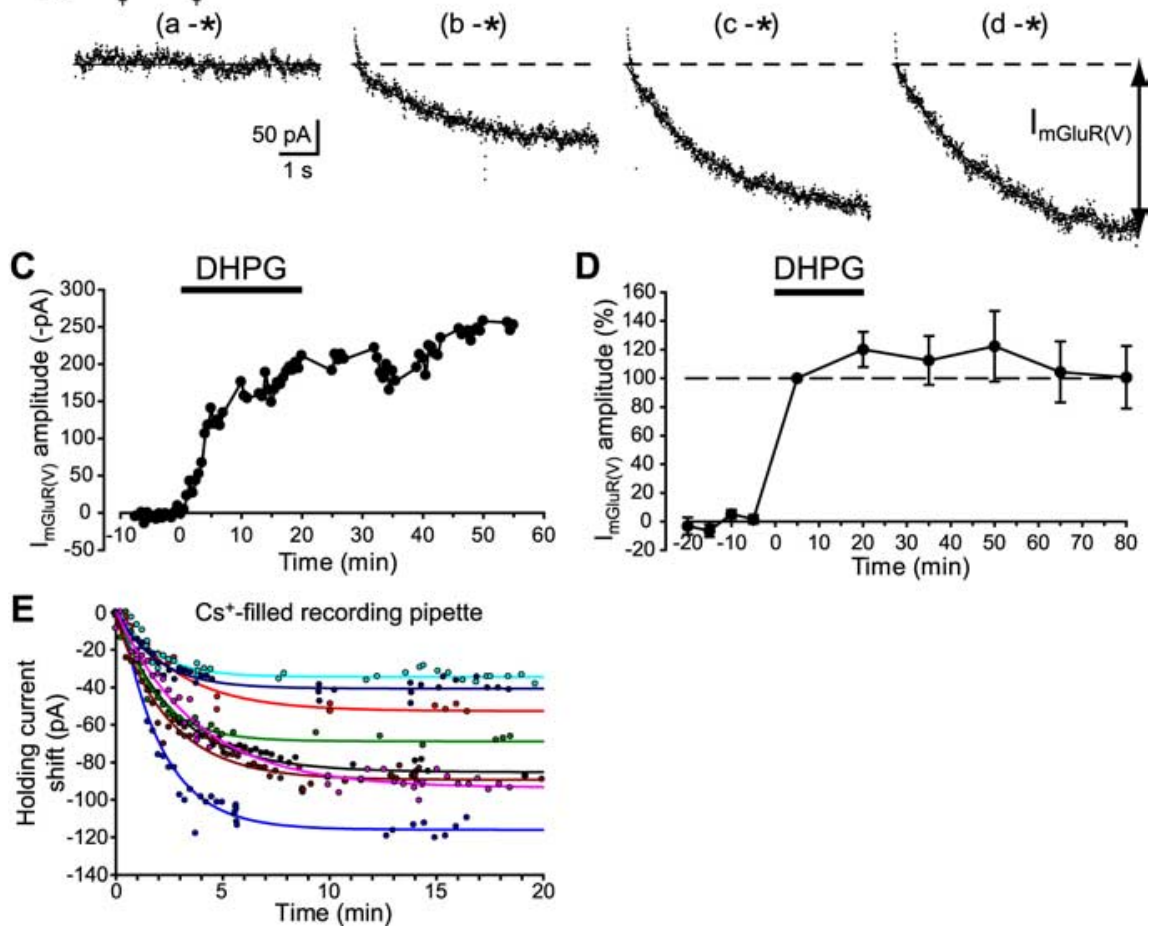

Figure 2. Long-lasting induction of $I_{\mathrm{mGluR}(\mathrm{V})}$ by DHPG. $A$, Whole-cell patch-clamp recordings of responses of a CA3 pyramidal cell to DHPG. Hyperpolarizing voltage steps (inset) were applied every $30 \mathrm{~s}$ throughout the recording. $\boldsymbol{B}$, Current responses to pulses in $\boldsymbol{A}$ are shown expanded in the insets. The net inward current elicited by DHPG $\left(I_{\text {mGluR(V) }}\right)$ after the pulses (segment between arrows in the voltage protocol in $\boldsymbol{a}$ ) was obtained by subtracting the control response $\left(^{*}\right)$ from the corresponding traces. C, Time course of the $I_{\text {mGluR(V) }}$ amplitude for the experiment shown in $A$. D, Summary data of $I_{m G l u R(V)}$ amplitude normalized to that recorded at $5 \mathrm{~min}$ DHPG in seven cells. $\boldsymbol{E}$, Shift of holding currents in eight cells recorded with Cs ${ }^{+}$-filled pipettes and voltage clamped at $-50 \mathrm{mV}$. Time 0 is the onset of successful whole-cell patch recording. Plots were well fitted with single exponentials

shows these measures for $I_{\mathrm{mGluR}(\mathrm{V})}$ activated in the presence of DHPG and during $1.5 \mathrm{~h}$ of washout. The data show that the properties of $I_{\mathrm{mGluR}(\mathrm{V})}$ were not altered by DHPG washout, further indicating that long-lasting $I_{\mathrm{mGluR}(\mathrm{V})}$ is induced by transient DHPG exposure.

The sensitivity of persistent $I_{\text {mGluR(V) }}$ to the competitive group I mGluR antagonist MCPG was examined (Fig. 5). In the first set of experiment, slices were pretreated with MCPG $(250 \mu \mathrm{M})$ for $10 \mathrm{~min}$. In the presence of MCPG, recordings from CA3 pyramidal cells show that application of DHPG $(50 \mu \mathrm{M})$ did not elicit $I_{\mathrm{mGluR}(\mathrm{V})}$ (Fig. $5 A b, B)$. In a second set of experiments, persistent $I_{\mathrm{mGluR}(\mathrm{V})}$ was recorded after DHPG washout (Fig. 5Ac, DHPG wash). MCPG (250 $\mu \mathrm{M})$ was then introduced into the perfusion solution. The amplitude of persistent $I_{\text {mGluR(V) }}$ was not affected by the blocker (Fig. $5 A c, B$ ). 
A

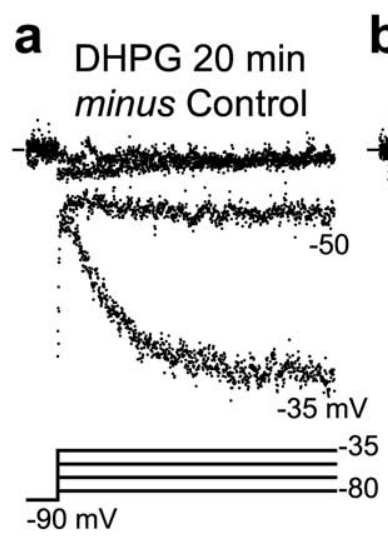

b

\section{Wash 45 min minus Control}

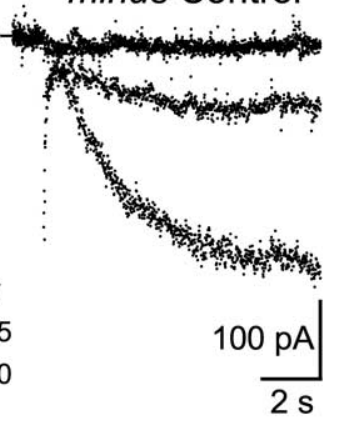

B

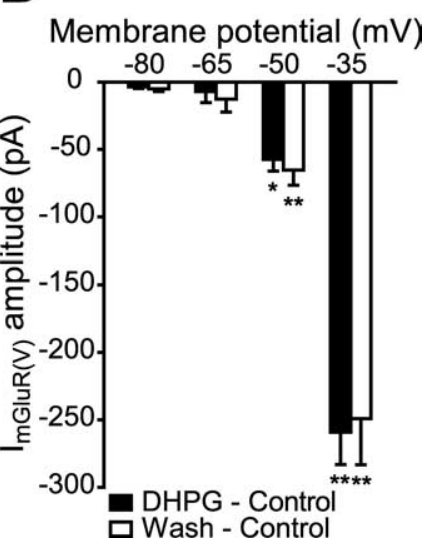

Figure 3. Long-lasting $I_{\mathrm{mGluR}(\mathrm{V})}$ is activated by depolarization. $\boldsymbol{A}, I_{\mathrm{mGluR}(\mathrm{V})}$ amplitude activated by depolarizing voltage steps (bottom) recorded during (a) and $45 \mathrm{~min}$ after $(\boldsymbol{b})$ DHPG washout. Records were obtained by subtraction of indicated current responses. TTX $(1 \mu \mathrm{M})$ and $\mathrm{Cs}^{+}(5 \mathrm{~mm})$ were present throughout the recording, performed with $\mathrm{Cs}^{+}{ }^{-}$-filled pipettes. $\boldsymbol{B}$, Average amplitude of $I_{\text {mGluR(V) }}$ activated by depolarizing pulses to the indicated levels during (filled bars) and $45 \mathrm{~min}$ after DHPG (hollow bars) in six cells. The amplitude of $I_{\text {mGluR(V) }}$ was maintained after DHPG washout $\left({ }^{*} p<0.01 ;{ }^{* *} p<0.05\right)$.

mediated discharges were recorded for at least $2 \mathrm{~h}$ after DHPG washout (Fig. $7 B b$ ). Antagonists of iGluRs were then added to the perfusing solution to suppress synchronized prolonged discharges and to facilitate voltage-clamp studies of individual CA3 or CA1 pyramidal cells. Hyperpolarizing pulses to $-110 \mathrm{mV}$ from a holding potential of $-45 \mathrm{mV}$ were used to measure $I_{\text {mGluR(V) }}$ activation. Posthyperpolarization current responses (Fig. 7Bc) were elicited in seven CA3 cells recorded from six slices that exhibited group I mGluRmediated prolonged discharges before the addition of iGluR blockers (Fig. 7E). Under the same condition, posthyperpolarization current responses were not detected in CA1 neurons recorded in the same slices (Fig. $7 B d, E)$. The latter result is consistent with previous findings that $I_{\mathrm{mGluR}(\mathrm{V})}$ can only be elicited in CA3, but not in CA1, pyramidal cells (Chuang et al., 2002).

Signaling mechanisms underlying $I_{\mathrm{mGluR}(\mathrm{V})}$ induction Previous studies showed that the induction of group I mGluRmediated prolonged epileptiform discharges requires activation of mRNA translation through a tyrosine kinase-ERK1/2 signaling pathway (Zhao et al., 2004; Chuang et al., 2005). We evaluated whether the induction of $I_{\mathrm{mGluR}(\mathrm{V})}$ by DHPG also involves a similar signaling mechanism.

Slices were preincubated in the tyrosine kinase inhibitor genistein $(30 \mu \mathrm{M})$ for at least $1 \mathrm{~h}$. Application of DHPG $(50 \mu \mathrm{M}$; $20 \mathrm{~min}$ ) under this condition elicited a transient inward current that lasted for a few minutes (3-15 $\min ; n=5)$ and faded in the presence of DHPG (Fig. 6A,B). Hyperpolarizing steps applied during the transient inward current elicited inward tail currents (posthyperpolarization current responses) indicative of $I_{\mathrm{mGluR}(\mathrm{V})}$ activation (Fig. 6A,B).

Similar to genistein, preincubation of inhibitors of ERK1/2 phosphorylation (PD98059, $50 \mu \mathrm{M}$; or U0126, $20 \mu \mathrm{M}$ ) or of protein synthesis (cycloheximide, $60 \mu \mathrm{M}$ ) resulted in the activation of transient inward currents that faded in the presence of DHPG. In addition, inward current responses were not detected after DHPG washout under any of these conditions (Fig. 6C).

These results indicate that the translational protein synthesis mediated via tyrosine kinase-ERK1/2 signaling is involved in $I_{\mathrm{mGluR}(\mathrm{V})}$ induction. These data parallel the results showing that induction of DHPG-activated prolonged epileptiform discharges was also suppressed by inhibitors of mRNA translation, tyrosine kinase, or ERK1/2 activation (Zhao et al., 2004; Chuang et al., 2005).

\section{Synaptic induction of $I_{\mathrm{mGluR}(\mathrm{V})}$}

Although group I mGluR-mediated prolonged epileptiform discharges are activated by the agonist DHPG in the wild-type preparation, stimulation of the glutamatergic recurrent synapses is ineffective in activating the group I mGluR-mediated prolonged discharges (Lee et al., 2002). In contrast, group I mGluRmediated prolonged discharges are synaptically induced in FXS mouse model preparations (Chuang et al., 2005). We examined whether synaptic stimulation was also effective in activating $I_{\mathrm{mGluR}(\mathrm{V})}$ in the FXS preparations.

Experiments were first performed in the wild-type preparations to measure $I_{\mathrm{mGluR}(\mathrm{V})}$ activation in association with the longlasting DHPG-induced discharges. Persistent group I mGluR-
Addition of bicuculline in wild-type preparations elicited short duration, interictal-like synchronized discharges in the pyramidal cell population (Fig. 7Ab). Each interictal-like discharge is sustained by the simultaneous activation of recurrent glutamatergic synapses between CA3 pyramidal cells (Traub and Wong, 1982). Voltage-clamp studies performed in CA3 or CA1 pyramidal cells after at least $2 \mathrm{~h}$ of interictal-like discharges showed absence of the posthyperpolarization current responses (Fig. $7 A c, A d)$, i.e., hyperpolarizing pulses did not elicit detectable inward current tails in either CA3 or CA1 cells (Fig. 7E).

In another set of experiments, slices from 2- to 4-week-old FXS (Fmr1-/-) mice were treated with bicuculline. Interictallike discharges ( $\sim 500 \mathrm{~ms}$ ) were first detected, as observed in the wild-type slices. After a period (25-60 min) of interictal discharge activity, prolonged $(>1.5 \mathrm{~s})$ discharges appeared in Fmr1-/- slices (Fig. 7Db). Slices exhibiting group I mGluRmediated prolonged discharges (Fig. $7 \mathrm{Db}$ ) were then perfused in a solution containing iGluR blockers, which suppressed the prolonged discharges. Measurement of posthyperpolarization current responses showed that $I_{\mathrm{mGluR(V)}}$ amplitudes recorded in CA3 neurons of Fmr1-/- slices that displayed prolonged discharges (Fig. 7Dc,E) were significantly larger than those recorded in CA3 neurons from Fmr1-/- slices that were not treated with bicuculline and did not display epileptiform discharges (Fig. 7Cc,E). $I_{\text {mGluR(V) }}$ was essentially not detected in CA1 neurons of Fmr1-/-slices either treated with bicuculline (Fig. $7 D d, E$ ) or in control conditions (Fig. $7 C d, E$ ).

The data above indicated that extended exposure to bicuculline induced group I mGluR-mediated prolonged epileptiform discharges in all slices isolated from 2- to 4-week-old Fmr1-/mice (seven of seven slices) (Fig. 7D,E). Additional experiments were performed to examine Fmr1-/- preparations from older (5-7 week) mice. These preparations exhibited a decreased susceptibility to bicuculline-induced epileptiform discharge prolongation (these data parallel the in vivo finding that susceptibility for audiogenic seizure peaked in younger, 2- to 4-week-old, FXS mice) (Yan et al., 2005). In older preparations, prolonged ( $\geq 1.5$ s) discharges were elicited in four of twelve slices, whereas short $(<1.5 \mathrm{~s})$, interictal-like discharges continued in the remaining eight slices during bicuculline exposures of up to $120 \mathrm{~min}$. In CA3 neurons of Fmr1-/- slices that displayed prolonged discharges, 
$I_{\text {mGluR(V) }}$ amplitude was significantly larger than the current recorded in CA3 neurons from Fmr1-/- slices that only exhibited interictal-like discharges (Fig. $7 F)$. Thus, significant $I_{\mathrm{mGluR}(\mathrm{V})}$ was induced in all CA3 cells from slices that exhibited prolonged discharges in both age groups, whereas negligible $I_{\mathrm{mGluR}(\mathrm{V})}$ was recorded in CA1 neurons of both groups of slices (Fig. $7 F$ ).

\section{Discussion}

The data of the present study point to $I_{\text {mGluR(V) }}$, a depolarization-activated inward current, as the cellular mechanism for group I mGluR-mediated epileptogenesis. To define a cellular event as a mechanism for epileptogenesis, at least three criteria must be satisfied: (1) the emergence of a form of epileptiform discharges is associated with the activation of this event; (2) the cellular event, once induced, must be long lasting to sustain persistent epileptiform discharges; and (3) the cellular event must be activatable by integrative activities of the neuronal circuit and must serve as a candidate for a form of epilepsy. Our data show that $I_{\mathrm{mGluR(V)}}$ activation satisfies all these criteria. The role of $I_{\mathrm{mGluR(V)}}$ in prolonged epileptiform discharges can be further defined by showing that blockade of $I_{\mathrm{mGluR}(\mathrm{V})}$ also suppresses the epileptiform discharges, as indicated by our initial data (supplemental Fig. S2, available at www.jneurosci.org as supplemental material). In addition, it remains to be determined whether $I_{\mathrm{mGluR}(\mathrm{V})}$ activation alone is sufficient to sustain this epileptiform activity. In this case, specific induction of $I_{\mathrm{mGluR}(\mathrm{V})}$ alone would be sufficient to sustain epileptiform discharges.

\section{Emergence of group I mGluR-mediated} epileptiform discharges is associated with $I_{\text {mGluR(V) }}$ activation

In addition to $I_{\mathrm{mGluR}(\mathrm{V})}$ activation, DHPG

also increases the cell's input resistance. In phospholipase $C \beta 1$ knock-out $(P L C \beta 1-/-)$ preparations, DHPG only increased the input resistance, but did not elicit $I_{\mathrm{mGluR}(\mathrm{V})}$. In the absence of $I_{\mathrm{mGluR(V)}}$, prolonged epileptiform discharges were also not generated in $P L C \beta 1-/$ - preparations (Chuang et al., 2001). Incorporation of $I_{\mathrm{mGluR}(\mathrm{V})}$ as an intrinsic current in CA3 pyramidal cells modified the firing pattern of single cells from spontaneous action potential firing to rhythmic prolonged periods of firing of up to $10 \mathrm{~s}$ (Fig. 1). Prolonged epileptiform discharges differ from single-cell firing in that the former consist of synchronized firing of the whole population activity. In our studies on single-cell properties, prolonged epileptiform discharges were desynchronized by applying iGluR blockers (Fig. 1). The data indicate that, once prolonged single-cell firing was elicited by DHPG, prolonged epileptiform discharges were generated via synaptic excitation mediated by iGluRs, which synchronized the activity of the from 11 CA3 pyramidal cells.
B

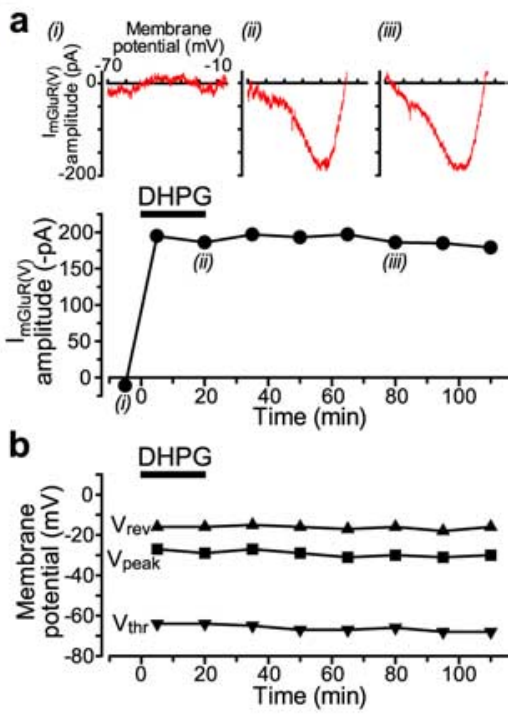

C

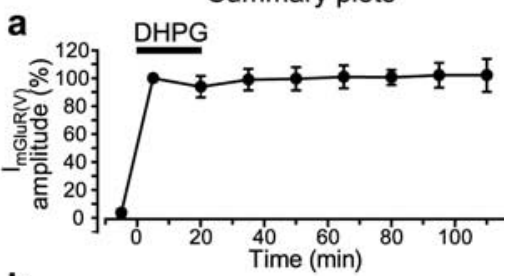

b

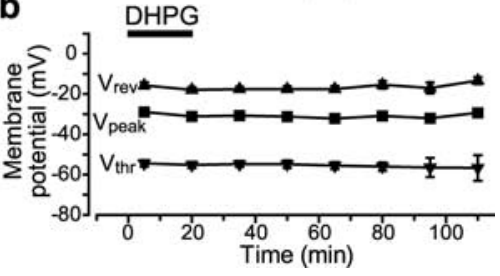

Figure 4. Activation properties of long-lasting $I_{\mathrm{mGluR(V})} \cdot \boldsymbol{A}$, Voltage-gated calcium currents were suppressed $(\boldsymbol{a})$ in a solution containing low $\mathrm{Ca}^{2+}(0.2 \mathrm{mM}), \mathrm{Mn}^{2+}(1 \mathrm{mM})$, TTX $(1 \mu \mathrm{M})$, and $\mathrm{Cs}^{+}(5 \mathrm{mM})$. Under this condition (Control), a linear current "sag" developed in the current response to the same ramp $(\boldsymbol{b}) . I-V$ plots (c) were obtained by subtracting the control curren (bo indicated responses. The $I-V$ plot provided values for the peak amplitude (arrow) and voltage

CA3 pyramidal cell population. The role of iGluR-dependent recurrent excitation between CA3 pyramidal cells in the generation of short epileptiform activities resembling interictal spikes has been well described (Traub and Wong, 1982). By prolonging single-cell firing, $I_{\mathrm{mGluR}(\mathrm{V})}$ provided the basic activity pattern which, when synchronized, produced the prolonged epileptiform discharges. $I_{\mathrm{mGluR}(\mathrm{V})}$ is an example of a transmitter-activated inward current that underlies intrinsic rhythmic bursting and contributes to network activities (Swensen and Marder, 2001).

Previous studies show that DHPG-induced prolonged epileptiform discharges can be suppressed by intervention in the signaling process downstream from group I mGluR activation. Specifically, inhibitors of tyrosine kinase, ERK1/2, and mRNA translation are each effective in preventing the induction of prolonged epileptiform discharges (Merlin et al., 1998; Zhao et al., 2004). We now show that each of these inhibitors also prevented the induction of $I_{\mathrm{mGluR}(\mathrm{V})}$ in CA3 pyramidal cells during DHPG 


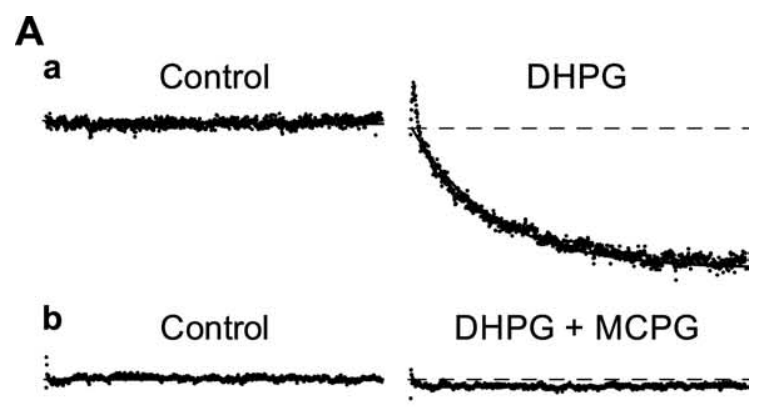

C

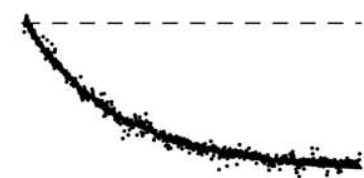

DHPG wash + MCPG

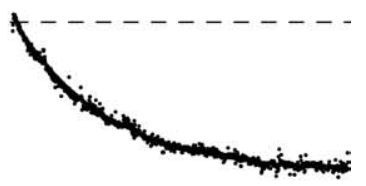

$\frac{50 \mathrm{pA}}{2 \mathrm{~s}}$

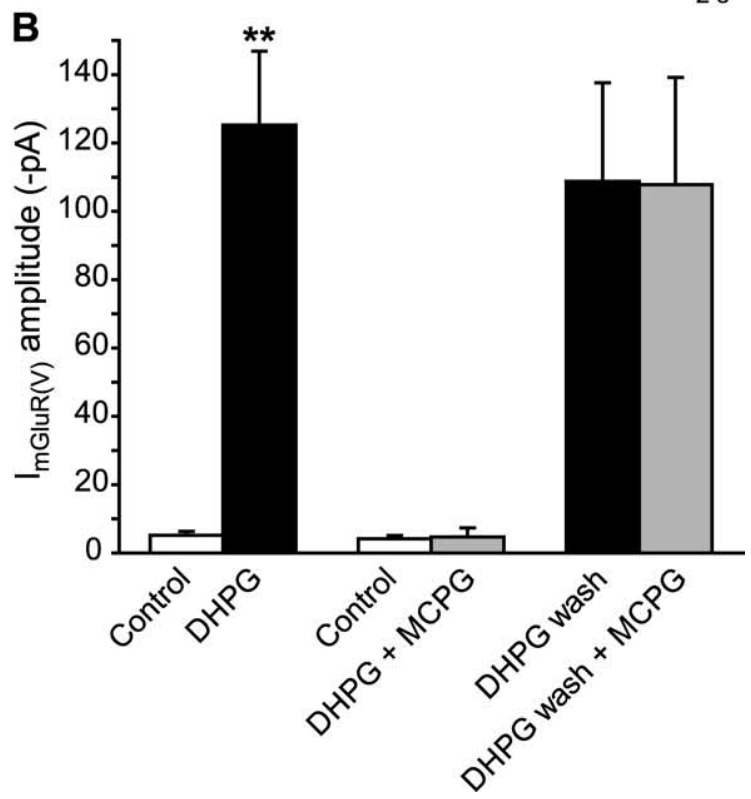

Figure 5. Long-lasting $I_{\text {mGluR(V) }}$ is not blocked by the competitive mGluR antagonist MCPG. $A$, Currents were elicited by depolarizing steps from -80 to $-45 \mathrm{mV}$. The currents shown were obtained by subtracting the corresponding control (i.e., before DHPG application) traces from the responses recorded in the indicated conditions ( $\boldsymbol{a}$, DHPG: after 5 min application of DHPG 50 $\mu \mathrm{m} ; \boldsymbol{b}$, DHPG plus MCPG: after 5 min DHPG $50 \mu \mathrm{m}$ applied in the presence of MCPG $250 \mu \mathrm{m} ; \boldsymbol{c}$, DHPG wash: after 30 min of DHPG washout; and $c$, DHPG wash plus MCPG: after application of MCPG $250 \mu \mathrm{m}$ for 40 min subsequent to DHPG washout, in the same group of cells shown as DHPG wash). As in Figure 1Dc, subtracted traces were fitted with single exponentials (solid lines). $\boldsymbol{B}$, Summary data of $I_{\mathrm{mGluR}(\mathrm{V})}$ amplitude in the different series of experiments indicated. Significant activation of $I_{\text {mGluR(V) }}\left(\mathrm{DHPG},-125.2 \pm 21.6 \mathrm{pA}\right.$ vs Control, $-5.2 \pm 1.1 \mathrm{pA} ; n=6$; ${ }^{* *} p<$ 0.01 , Student's paired $t$ test) was prevented in the presence of MCPG $250 \mu \mathrm{m}$ (DHPG plus MCPG, $-4.6 \pm 2.7 \mathrm{pA}$ vs Control, $-4.1 \pm 1.0 \mathrm{pA} ; n=5 ; p=0.90)$. In contrast, $I_{\text {mGluR(v) }}$ persisting after DHPG washout was not affected by the same concentration of the antagonist (DHPG wash plus MCPG, $-107.8 \pm 31.5 \mathrm{pA}$ vs DHPG wash, $-108.8 \pm 28.9 \mathrm{pA} ; n=6 ; p=0.85$ ).

stimulation. In the presence of these blockers, DHPG elicited a transient inward current response which faded even in the presence of the agonist (Fig. 6C). Other long-lasting DHPG-elicited responses, such as long-term synaptic depression and persistent post-spike afterhyperpolarization suppression, are also transiently activated when protein synthesis is inhibited (Huber et al., 2000; Young et al., 2008). Apparently, protein synthesis is only required to maintain the persistency of the responses.

The association of $I_{\mathrm{mGluR}(\mathrm{V})}$ with prolonged epileptiform discharges is further indicated by our initial results (supplemental Fig. S2, available at www.jneurosci.org as supplemental material): lidocaine blocked the generation of prolonged epileptiform discharges, presumably via a specific suppression of $I_{\mathrm{mGluR}(\mathrm{V})}$, suggesting a direct role of $I_{\mathrm{mGluR}(\mathrm{V})}$ in prolonged epileptiform discharge generation.

$I_{\mathrm{mGluR}(\mathrm{V})}$, once induced, is long lasting

The fact that DHPG-induced prolonged epileptiform discharges are long lasting and the finding that $I_{\mathrm{mGluR}(\mathrm{V})}$ plays a fundamental role in patterning prolonged epileptiform discharges suggest that long-lasting $I_{\mathrm{mGluR}(\mathrm{V})}$ occurs to sustain the prolonged epileptiform discharges. The data show that $I_{\mathrm{mGluR}(\mathrm{V})}$, once induced in CA3 pyramidal cells, became a component of the intrinsic current which defined the cell's basic membrane properties. Activation of $I_{\mathrm{mGluR}(\mathrm{V})}$ after its induction was solely determined by transmembrane voltage and was dissociated from group I mGluR activation. Figures 2 and 4 show that the amplitude of $I_{\text {mGluR(V) }}$ remained undiminished over hours of washout. Prolonged epileptiform discharges induced by DHPG are also maintained for hours after agonist application (Merlin and Wong, 1997). These robust plastic changes induced by DHPG are those that define the DHPG responses as "epileptogenic" and $I_{\mathrm{mGluR}(\mathrm{V})}$ as a mechanism associated with epileptogenesis.

Persistency of the plastic change brings into question as to why $I_{\text {mGluR(V) }}$ was not detectable in CA3 cells before DHPG stimulation, especially in view of data showing that group I mGluRs are stimulated by synaptic activities (Fig. $7 D c$ ). The data show that induction of $I_{\mathrm{mGluR}(\mathrm{V})}$, similar to that of the group I mGluRmediated prolonged epileptiform discharges (Chuang et al., 2005), is tightly controlled by the repressive action of FMRP, such that normal synaptic stimulation of group I mGluRs is ineffective in activating the mRNA translation necessary for $I_{\mathrm{mGluR}(\mathrm{V})}$ induction (Fig. 8).

$I_{\text {mGluR(V) }}$ is activated by synchronized synaptic activity and is implicated in epilepsy associated with fragile $\mathrm{X}$ syndrome

The relevance of experiments showing DHPG-induced epileptiform discharges to the study of epileptogenesis is indicated by the data obtained in the FXS model mouse. Here, prolonged epileptiform activity was induced by synaptically released glutamate. Furthermore, it has been shown that enhanced audiogenic seizures in FXS mice is prevented by specific mGluR5 antagonism (Yan et al., 2005). To examine whether $I_{\mathrm{mGluR}(\mathrm{V})}$ could be induced synaptically in a CA3 pyramidal cell, we studied the effect of simultaneous activation of all the recurrent synapses of neighboring CA3 pyramidal cells onto that cell by taking advantage of a property of the CA3 circuit. CA3 pyramidal cells are densely interconnected via glutamatergic synapses. One CA3 pyramidal cell can receive as many as 650 synaptic inputs from neighboring cells (Wittner and Miles, 2007). The recurrent connections are sufficiently strong that firing in one neuron activates a few postsynaptic cells and, in the absence of inhibitory control (such as in the presence of bicuculline), cell firing spreads through the entire CA3 population within $\sim 200 \mathrm{~ms}$ and results in a synchronized discharge (Miles and Wong, 1983). Within a synchronized discharge, each pyramidal cell is stimulated by the recurrent synapses from all the projecting presynaptic cells (Traub and Wong, 


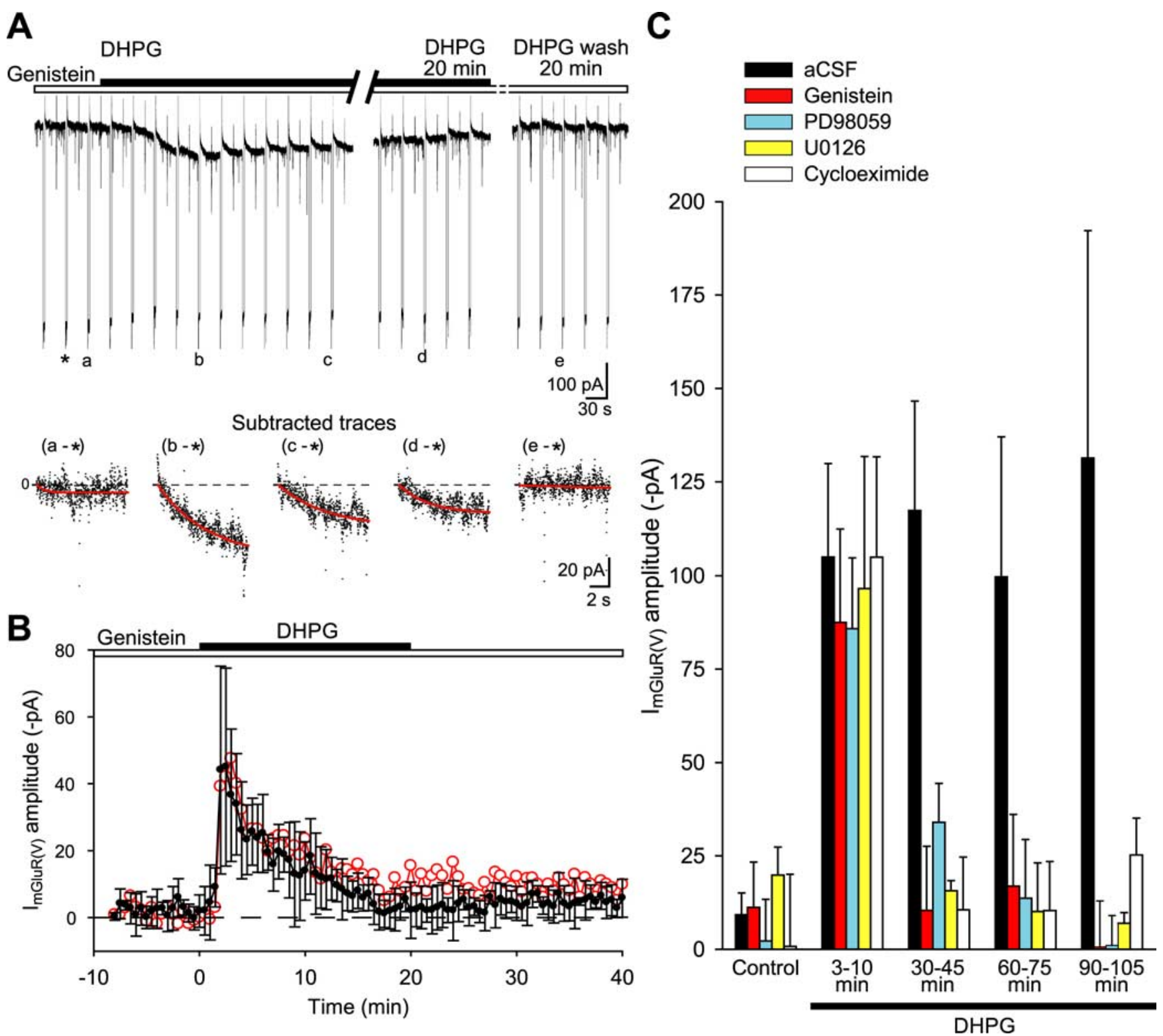

Figure 6. Long-lasting $I_{\text {mGluR(V) }}$ is suppressed by inhibitors of tyrosine kinase, ERK1/2, and protein synthesis. $A$, Current responses of a CA3 pyramidal cell to hyperpolarizing voltage steps from -75 to $-45 \mathrm{mV}$ (downward deflections) before, during (filled bar), and after DHPG in the continuous presence of the tyrosine kinase inhibitor genistein ( $30 \mu \mathrm{M}$; hollow bar). $I_{\mathrm{mGluR}(\mathrm{V})}$ elicited after the hyperpolarizing pulse was obtained by subtracting the control response ${ }^{*}$ ) from the corresponding indicated responses (Subtracted traces). Red lines are single exponential fits. $\boldsymbol{B}$, Time course of $I_{\text {mGluR(V) }}$ amplitude for the cell shown in $\boldsymbol{A}$ (red circles) and summary data plot for five cells (filled circles). $C$, Mean $I_{\text {mGluR(V) }}$ amplitude recorded in control and in DHPG (aCSF; $n=8$ ), in DHPG plus genistein $(n=4)$, in DHPG plus PD98059 ( $n=3)$, in DHPG plus U0126 $(n=3)$, in DHPG plus cycloheximide $(n=4)$. In each experiment, agents were added 60 min before DHPG. Peak $I_{\text {mGluR(V) }}$ activation was observed in all experimental conditions with blockers after 3-10 min of DHPG application.

1982). Each synaptic input also activates both postsynaptic iGluRs and group I mGluRs. The data from wild-type preparations show that synaptic activation of group I mGluRs (without added DHPG) did not elicit $I_{\text {mGluR(V) }}($ Fig. $7 \mathrm{Bc}$ ). In contrast, in the FXS model mouse, synaptic stimulation in a similar manner elicited prolonged epileptiform discharges in a majority of the preparations (Fig. $7 \mathrm{Db}$ ) and prominent $I_{\mathrm{mGluR}(\mathrm{V})}$ in CA3 pyramidal cells of preparations exhibiting prolonged epileptiform discharges (Fig. $7 D c$ ). The data are consistent with previous findings, suggesting that group I mGluR-dependent responses are exaggerated in FXS preparations because of the absence of the repressive control by FMRP on the group I mGluR-stimulated mRNA translation (Fig. 8) (Bear et al., 2004).

Although $I_{\text {mGluR(V) }}$ was elicited by the simultaneous activation of recurrent synapses during a synchronized discharge, our data also reveal that the current was not detectable in CA3 pyramidal cells of the FXS preparation in the absence of such synchronized discharges. The simplest explanation for this observation is that, in the absence of synchronized discharges, the amplitude of $I_{\mathrm{mGluR}(\mathrm{V})}$ elicited in a CA3 pyramidal cell by the stochastic firing of the presynaptic population was small and was not detected by our somatic recording. Only with simultaneous synaptic activation of the entire population, $I_{\text {mGluR(V) }}$ became sufficiently large that it could be detected at the somatic site. Thus, in this extreme case, the consequence of a synaptically induced plastic change was no longer confined to the specific synapse but was extended to affect the response of the entire neuron. Our data indicate that the induction of $I_{\mathrm{mGluR}(\mathrm{V})}$, as a form of synaptic plasticity mechanism underlying epileptogenesis, is not a synapse-specific event, but rather leads to modifications that cause global changes in the neuron properties. 

A
Wild type
B
a
Control
Wild type
Fmr1-/-
Fmr1-/-
a
Control
Control
Control
D
a

$-72 \mathrm{mV}$

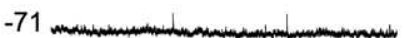

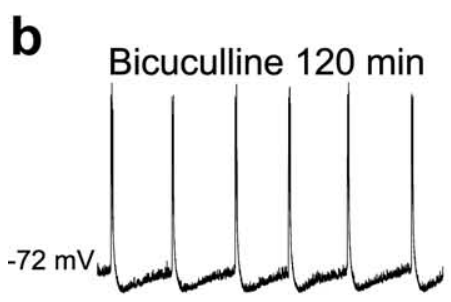

b Post-DHPG 120 min

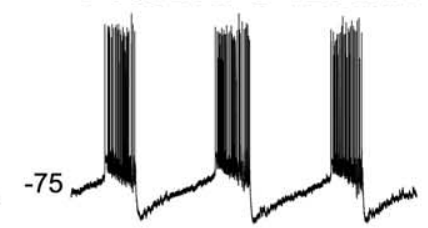

C

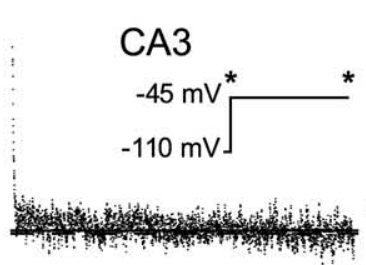

C

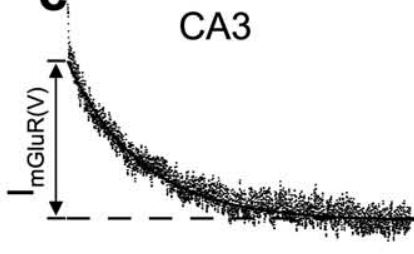

d

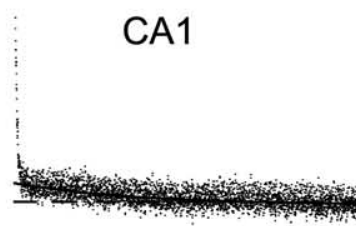

d

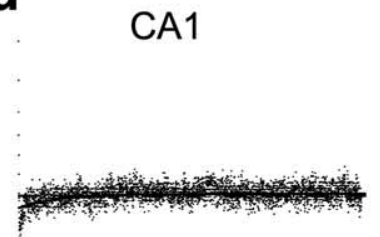

$-69$

b Control 120 min

$-67$

b Bicuculline $120 \mathrm{~min}$

$-68$

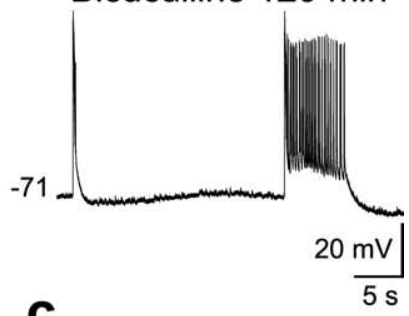

C

CA3

CA3

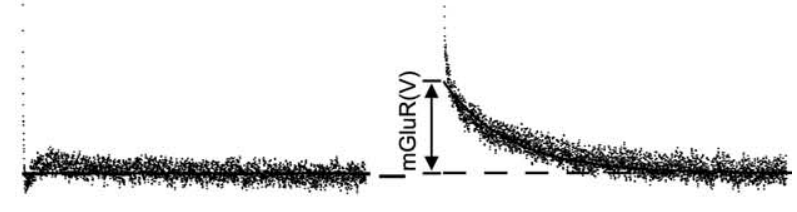

d

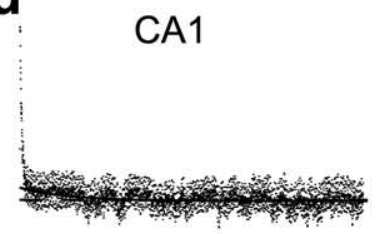

CA1

$\mathbf{F}$

Age 2-4 wk + 5-7 wk

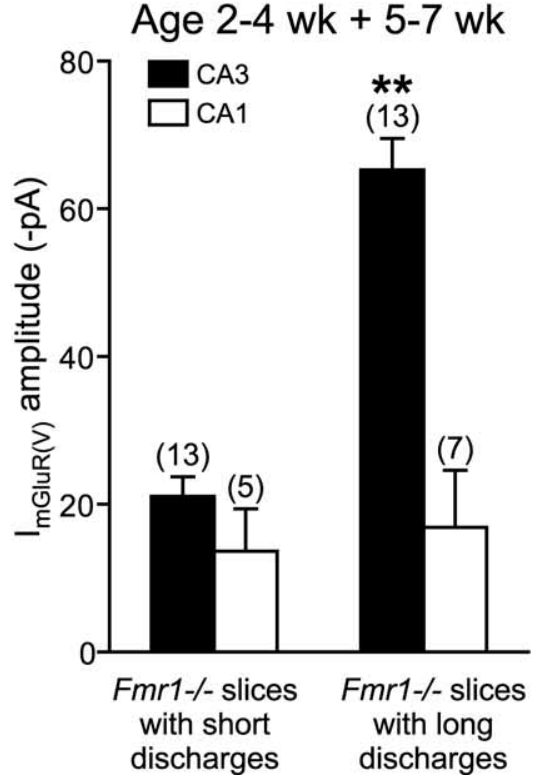

Age 2-4 wk

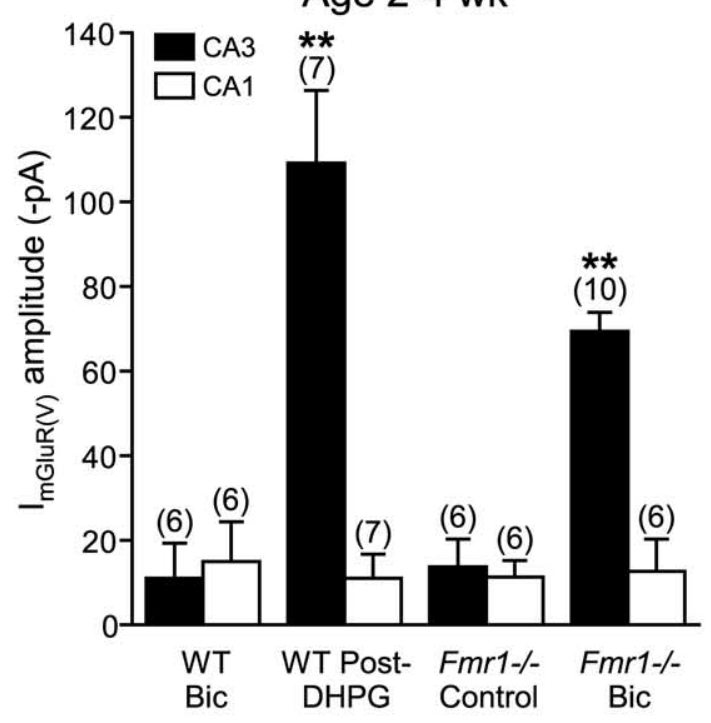

Figure 7. Agonist-induced or synaptically induced $I_{m G l u R(v)}$ underlies prolonged epileptiform discharges. $A$, Intracellular recordings from a CA3 pyramidal cell in control solution (aCSF; $a$ ) and 120 min after addition of bicuculline $50 \mu \mathrm{m}(\boldsymbol{b})$. The burst firing represents short duration ( $300-500 \mathrm{~ms})$ synchronized discharges of the CA3 population. The same cell was recorded in CNQX and CPP after the bicuculline treatment (c). $I_{\text {mGluR(V) }}$ amplitude at $-45 \mathrm{mV}$, activated after a hyperpolarizing pulse to $-110 \mathrm{mV}$, was measured under voltage clamp. In this condition, $I_{\mathrm{mGluR}(\mathrm{V})}$ was negligible. A CA1 cell in the same slice was recorded under the same condition (d). B, Prolonged epileptiform discharges induced by DHPG persisted after agonist washout (b). Addition of CNQX and CPP blocked the synchronized discharges. $I_{\mathrm{mGluR}(\mathrm{V})}$ amplitude activated in the same cell was measured under voltage clamp (c). A CA1 cell in the same slice was recorded under the same condition $(\boldsymbol{d})$. $\boldsymbol{C}$ and $\boldsymbol{D}$, CA3 pyramidal cells from Fmr1 - / - mice. C, In aCSF, ImGluR(v) was negligible in both CA3 (c) and CA1 (d) cells. D, Bicuculline induced group ImGluR-mediated prolonged epileptiform discharges (b). In the same cell, recorded in CNQX and CPP to suppress the epileptiform discharges, $I_{\text {mGluR(V) }}$ was observed in CA3 (c) but not in CA1 (d) cells. $\boldsymbol{E}$, Summary data of $I_{\text {mGluR(V) }}$ amplitude under the different conditions in $(\boldsymbol{A}-\boldsymbol{D} \boldsymbol{c}, \boldsymbol{d})$. Data are from 2- to 4- week-old (young) mice. Numbers of cells are indicated in parenthesis ( $\left.{ }^{* *} p<0.01\right)$. $\boldsymbol{F}$, Mean $I_{\text {mGlur(v) }}$ amplitude in CA3 and CA1 cells recorded in slices isolated from Fmr1 - / - mice that showed interictal (short; $<1.5 \mathrm{~s}$ ) and prolonged epileptiform (long; $\geq 1.5 \mathrm{~s}$ ) discharges. Data are pooled from young and older ( $5-7$ week) mice. Bic, Bicuculline. 
The exaggerated group I mGluRmediated responses recorded in the FXS preparation is paralleled by the propensity for epileptogenesis in FXS model mice. FXS model mice showed increased seizure vulnerability in response to audio stimuli (Musumeci et al., 2000; Chen and Toth, 2001). This form of audiogenic seizures is group I mGluR-mediated as it is suppressed by the group I mGluR subtype blocker MPEP (Yan et al., 2005). In addition, audiogenic seizure susceptibility shows an age dependency with vulnerability peaking at 20-21 d of age (Yan et al., 2005). Our data show a similar agedependent pattern in the efficacy of synaptic induction of $I_{\mathrm{mGluR}(\mathrm{V})}$ in the in vitro preparation (Fig. 6E,F). Finally, experimental data in vitro and in vivo strongly suggest that, in the absence of FMRP regulation, age-dependent increased propensity for epilepsy in FXS patient (Wisniewski et al., 1991) may be caused by dysregulation of group I mGluRstimulated mRNA translation. Accordingly, activation of $I_{\mathrm{mGluR}(\mathrm{V})}$ may constitute a cellular mechanism for epileptogenesis in FXS patients.

\section{References}

Aschrafi A, Cunningham BA, Edelman GM, Vanderklish PW (2005) The fragile X mental retardation protein and group I metabotropic glutamate receptors regulate levels of mRNA granules in brain. Proc Natl Acad Sci U S A 102:2180-2185.

Bear MF, Huber KM, Warren ST (2004) The mGluR theory of fragile X mental retardation. Trends Neurosci 27:370-377.

Bianchi R, Wong RKS (1995) Excitatory synaptic potentials dependent on metabotropic glutamate receptor activation in guinea-pig hippocampal pyramidal cells. J Physiol 487:663-676.

Bianchi R, Young SR, Wong RKS (1999) Group I mGluR activation causes voltage-dependent and -independent $\mathrm{Ca}^{2+}$ rises in hippocampal pyramidal cells. J Neurophysiol 81:2903-2913.

Bianchi R, Chuang SC, Wong RKS (2006) Pharmacology of a slowly inactivating outward current in hippocampal CA3 pyramidal neurons. J Neurophysiol 96:1116-1123.

Brickley SG, Farrant M, Swanson GT, Cull-Candy SG (2001) CNQX increases GABA-mediated synaptic transmission in the cerebellum by an AMPA/kainate receptor-independent mechanism. Neuropharmacology 41:730-736.

Chen L, Toth M (2001) Fragile X mice develop sensory hyperreactivity to auditory stimuli. Neuroscience 103:1043-1050.

Chuang SC, Bianchi R, Wong RKS (2000) Group I mGluR activation turns on a voltage-gated inward current in hippocampal pyramidal cells. J Neurophysiol 83:2844-2853.

Chuang SC, Bianchi R, Kim D, Shin HS, Wong RKS (2001) Group I metabotropic glutamate receptors elicit epileptiform discharges in the hippocampus through PLC $\beta 1$ signaling. J Neurosci 21:6387-6394.

Chuang SC, Zhao W, Young SR, Conquet F, Bianchi R, Wong RKS (2002) Activation of group I mGluRs elicits different responses in murine CA1 and CA3 pyramidal cells. J Physiol 541:113-121.

Chuang SC, Zhao W, Bauchwitz R, Yan Q, Bianchi R, Wong RKS (2005) Prolonged epileptiform discharges induced by altered group I metabotropic glutamate receptor-mediated synaptic responses in hippocampal slices of a fragile X mouse model. J Neurosci 25:8048-8055.

Hashimoto Y, Miyakawa H, Kudo Y, Inoue M (2004) 6-Cyano-7nitroquinoxaline-2,3-dione $(\mathrm{CNQX})$ increases $\mathrm{GABA}_{\mathrm{A}}$ receptor- mediated spontaneous postsynaptic currents in the dentate granule cells of rat hippocampal slices. Neurosci Lett 358:33-36.

Hou L, Antion MD, Hu D, Spencer CM, Paylor R, Klann E (2006) Dynamic translational and proteasomal regulation of fragile $\mathrm{X}$ mental retardation protein controls mGluR-dependent long-term depression. Neuron 51:441-454.

Huber KM, Kayser MS, Bear MF (2000) Role for rapid dendritic protein synthesis in hippocampal mGluR-dependent long-term depression. Science 288:1254-1257.

Huber KM, Gallagher SM, Warren ST, Bear MF (2002) Altered synaptic plasticity in a mouse model of fragile X mental retardation. Proc Natl Acad Sci U S A 99:7746-7750.

Lee AC, Wong RK, Chuang SC, Shin HS, Bianchi R (2002) Role of synaptic metabotropic glutamate receptors in epileptiform discharges in hippocampal slices. J Neurophysiol 88:1625-1633.

Lieb JP, Engel J Jr, Gevins A, Crandal PH (1981) Surface and deep EEG correlates of surgical outcome in temporal lobe epilepsy. Epilepsia 22:515-538.

Maccaferri G, Dingledine R (2002) Complex effects of CNQX on CA1 interneurons of the developing rat hippocampus. Neuropharmacology 43:523-529.

McBain CJ, Eaton JV, Brown T, Dingledine R (1992) CNQX increases spontaneous inhibitory input to CA3 pyramidal neurones in neonatal rat hippocampal slices. Brain Res 592:255-260.

McNamara JO, Huang YZ, Leonard AS (2006) Molecular signaling mechanisms underlying epileptogenesis. Sci STKE 2006:re12.

Menuz K, Stroud RM, Nicoll RA, Hays FA (2007) TARP auxiliary subunits switch AMPA receptor antagonists into partial agonists. Science 318:815-817.

Merlin LR, Wong RKS (1997) Role of group I metabotropic glutamate receptors in the patterning of epileptiform activities in vitro. J Neurophysiol 78:539-544.

Merlin LR, Bergold PJ, Wong RKS (1998) Requirement of protein synthesis 
for group I mGluR-mediated induction of epileptiform discharges. J Neurophysiol 80:989-993.

Miles R, Wong RKS (1983) Single neurones can initiate synchronized population discharge in the hippocampus. Nature 306:371-373.

Musumeci SA, Bosco P, Calabrese G, Bakker C, De Sarro GB, Elia M, Ferri R, Oostra BA (2000) Audiogenic seizures susceptibility in transgenic mice with fragile X syndrome. Epilepsia 41:19-23.

Penagarikano O, Mulle JG, Warren ST (2007) The pathophysiology of fragile x syndrome. Annu Rev Genomics Hum Genet 8:109-129.

Rae MG, Irving AJ (2004) Both mGluR1 and mGluR5 mediate $\mathrm{Ca}^{2+}$ release and inward currents in hippocampal CA1 pyramidal neurons. Neuropharmacology 46:1057-1069.

Raley-Susman KM, Kass IS, Cottrell JE, Newman RB, Chambers G, Wang J (2001) Sodium influx blockade and hypoxic damage to CA1 pyramidal neurons in rat hippocampal slices. J Neurophysiol 86:2715-2726.

Swensen AM, Marder E (2001) Modulators with convergent cellular actions elicit distinct circuit outputs. J Neurosci 21:4050-4058.

Taylor GW, Merlin LR, Wong RKS (1995) Synchronized oscillations in hippocampal CA3 neurons induced by metabotropic glutamate receptor activation. J Neurosci 15:8039-8052.

Traub RD, Wong RKS (1982) Cellular mechanism of neuronal synchronization in epilepsy. Science 216:745-747.
Weiler IJ, Irwin SA, Klintsova AY, Spencer CM, Brazelton AD, Miyashiro K, Comery TA, Patel B, Eberwine J, Greenough WT (1997) Fragile X mental retardation protein is translated near synapses in response to neurotransmitter activation. Proc Natl Acad Sci U S A 94:5395-5400.

Wisniewski KE, Segan SM, Miezejeski CM, Sersen EA, Rudelli RD (1991) The $\operatorname{Fra}(\mathrm{X})$ syndrome: neurological, electrophysiological, and neuropathological abnormalities. Am J Med Genet 38:476-480.

Wittner L, Miles R (2007) Factors defining a pacemaker region for synchrony in the hippocampus. J Physiol 584:867-883.

Wong RK, Chuang SC, Bianchi R (2004) Plasticity mechanisms underlying mGluR-induced epileptogenesis. Adv Exp Med Biol 548:69-75.

Yan QJ, Rammal M, Tranfaglia M, Bauchwitz RP (2005) Suppression of two major Fragile X Syndrome mouse model phenotypes by the mGluR5 antagonist MPEP. Neuropharmacology 49:1053-1066.

Young SR, Bianchi R, Wong RKS (2008) Signaling mechanisms underlying group I mGluR-induced persistent AHP suppression in CA3 hippocampal neurons. J Neurophysiol 99:1105-1118.

Zhao W, Bianchi R, Wang M, Wong RKS (2004) Extracellular signalregulated kinase $1 / 2$ is required for the induction of group I metabotropic glutamate receptor-mediated epileptiform discharges. J Neurosci 24:7684 . 